\title{
Plants Species Diversity along River Benue Bank under the Influence of Siltation and Solid Waste Effluents, Adamawa State, Nigeria
}

\author{
J. E. Adaeze, E. E. Dishan, I. O. Tella \\ Department of Forestry and Wildlife Management, Modibbo Adama University of Technology, Yola, Nigeria \\ Email: enebuseja@gmail.com
}

How to cite this paper: Adaeze, J.E., Dishan, E.E. and Tella, I.O. (2017) Plants Species Diversity along River Benue Bank under the Influence of Siltation and Solid Waste Effluents, Adamawa State, Nigeria. Open Access Library Journal, 4: e4125. https://doi.org/10.4236/oalib.1104125

Received: November 7, 2017

Accepted: December 25, 2017

Published: December 28, 2017

Copyright (c) 2017 by authors and Open Access Library Inc.

This work is licensed under the Creative Commons Attribution International License (CC BY 4.0).

http://creativecommons.org/licenses/by/4.0/

\begin{abstract}
This research was aimed at assessing plants diversity, under the influence of siltation and solid waste effluents along the River Benue bank, Shinko area in Yola North Local Government Area of Adamawa State, Nigeria. Three plots of $20 \mathrm{~m} \times 20 \mathrm{~m}$ were randomly established at the solid waste, silt + solid waste, silted and no-silt; no-waste areas. A quadrat of $1 \mathrm{~m} \times 1 \mathrm{~m}$ was laid at random to determine the population of plant species in each plot. The results of the population of plant species in the various sites revealed that, 10 plant species occurred at the solid waste area (SWA), 7 species at silt + waste area (SSW), 12 plant species at silted area (SA) and 31 plant species at no-silt; no-waste area (NSW). Shannon-Wiener's diversity index was used to analyse species diversity in the various sampling locations. Shannon-Wiener's diversity indexes in the various sites were approximately 1.985, 1.788, 2.140 and 3.125 at SWA, SSW, SA and NSW respectively. The result obtained indicates high uncertainties; as each species are relatively distributed within SWA, SSW, SA and NSW areas. The results indicated that there were significant differences at $\mathrm{P} \geq 0.05$ as (p-value $=0.183377)$ in plant species among the study sites. Axonopus compressus had the highest occurrence in 3 of the study areas, except for the silted area.
\end{abstract}

\section{Subject Areas}

Biodiversity

\section{Keywords}

Distribution, Plant Species, Siltation, River Benue Bank

\section{Introduction}

The set of species that can be present at a given site is limited by historical con- 
tingency. In order to show up, a species must either have evolved in an area or dispersed there (either naturally or through anthropogenic activities), and must not have gone locally extinct. The set of species present locally is further limited to those that possess the physiological adaptations to survive the environmental conditions that exist. This group is further shaped through interactions with other species [1]. Plant communities are broadly distributed into biomes based on the form of the dominant plant species. For example, grasslands are dominated by grasses, while forests are dominated by trees. Biomes are determined by regional climates, mostly temperature and precipitation, and follow general latitudinal trends. In principle, it is possible to examine competition at the level of the limiting resources if a detailed knowledge of the physiological processes of the competing plants is available. However, in most terrestrial ecological studies, there is only little information on the uptake and dynamics of the resources that limit the growth of different plant species, and, instead, competition is inferred from observed negative effects of neighbouring plants without knowing precisely which resources the plants were competing for. In certain situations, plants may compete for a single growth-limiting resource, perhaps for light in agricultural systems with sufficient water and nutrients, or in dense stands of marsh vegetation, but in many natural ecosystems plants may be co-limited by several resources, e.g. siltation, light, phosphorus and nitrogen at the same time [1].

Environmental conditions play a key role in defining the function and distribution of plants, in combination with other factors. Changes in long term environmental conditions that can be collectively coined climate change are known to have had enormous impacts on plant diversity patterns in the future and are seen as having significant current impacts. It is predicted that climate change will remain one of the major drivers of biodiversity patterns in the future [2]. Individual plant species can only function physiologically, and successfully complete their life cycles under specific environmental conditions (ideally within a subset of these); changes to climate are likely to have significant impacts on plants from the level of the individual right through to the level of the ecosystem or biome [3].

The inadequate information about the present status of most habitats and species both in protected areas and the natural environment makes management difficult. It has long been feared that human activity is causing massive extinctions. Despite increased efforts at conservation, it has not been enough and biodiversity losses continue [1]. The costs associated with deteriorating or vanishing ecosystems will be high if anthropogenic activities are not checked to know the status of plants in the study area. The general aim of this study was to investigate plants species occurrence in the study area under the influence of siltation and solid waste effluents. The specific objective was to prepare a checklist of plants in the study area. The study focused only on investigating the diversity of plants along River Benue bank in Adamawa state. The study was limited to the dumping site along the Doubeli bypass road by Shinko community.

The Benue River is a river in Africa. It is the major tributary of the Niger Riv- 
er. The river is about $1400 \mathrm{~km}$ long. It starts in the Adamawa Plateau of northern Cameroon. In the catchment area there is a very high level of plant endemism. Plant endemism in the upper catchment of the Benue is very high, with trees such as Anogeissus leiocarpus, Kigelia aethiopica, Acacia seyal, Combretum and Terminalia species. Grass cover often features the Elephant Grass (Cenchrus purpureum). The lower basin of the Benue River can be construed as the region below the joining of the Gongola River at the town of Numan, northwest (downstream) of Yola (Jimeta). In the northern part of this area the terrestrial ecoregion is characterised chiefly by the sprawling floodplain of the West Sudanian savannah, while Guinean forest-savannah mosaic covers much southern part of the lower basin, [4] [5].

\section{Materials and Methods}

The study was carried out along Doubeli bypass road, in Shinko Ward of Yola North Local Government Area, Adamawa State at the on-set of the dry season, between latitudes $9^{\circ} 7^{\prime} 30^{\prime \prime}$ and $10^{\circ} 50^{\prime \prime} \mathrm{N}$, and longitude $11^{\circ} 40^{\prime \prime}$ and $13^{\circ} 20^{\prime \prime} \mathrm{E}$ (Figure 1 \& Figure 2). This area is comprised of both indigenous and exotic flora and fauna species [6]. There are two notable vegetation zones in the state; the sub-Sudan zone and the northern guinea savannah zone. The vegetation of the study area is a savannah land; having sparse vegetation. It is comprised of grasses, shrubs and few trees of which some are exotic and others indigenous. Topographically, the study area is flat crossed by the River Benue [7].

Generally, mean annual rainfall is less than $1000 \mathrm{~mm}$ in the central and North western part of the state. Annual distribution of rainfall is said to be influenced by altitude of the stations which is reflected in the orientation of the isohyets which exhibit strong correlation with highland ranges. Rain usually starts from April in the south to and May in the North while cessation dates are from September in the North to and November in the extreme south. Mean length of rainy season ranges from 120 - 210 days in the state.

According to [8], Adamawa State air temperature is as it obtains in the rest of West African savannah. In this, the high radiation income which is relatively evenly distributed throughout the year is responsible for high temperature. Gradual temperature increase is usually experienced from January to April. Effect of cloudiness usually brings about distinct drop in temperature at the onset of rains. However a slight increase is usually experienced after cessation of rains i.e. October - November before the setting in of harmattan in December, during which time, temperature drops further. Thus minimum temperature can be as low as $18^{\circ} \mathrm{C}$ from December-January while maximum temperature can reach $40^{\circ} \mathrm{C}$ around April Average monthly temperature ranges from $26^{\circ} \mathrm{C}$ in the south to $27.8^{\circ} \mathrm{C}$ in the Eastern part.

\subsection{Data Collection and Analysis}

Three plots of $20 \mathrm{~m} \times 20 \mathrm{~m}$ were randomly selected in each of the sites using [9] [10] methods. Plant communities were established into four natural representative 


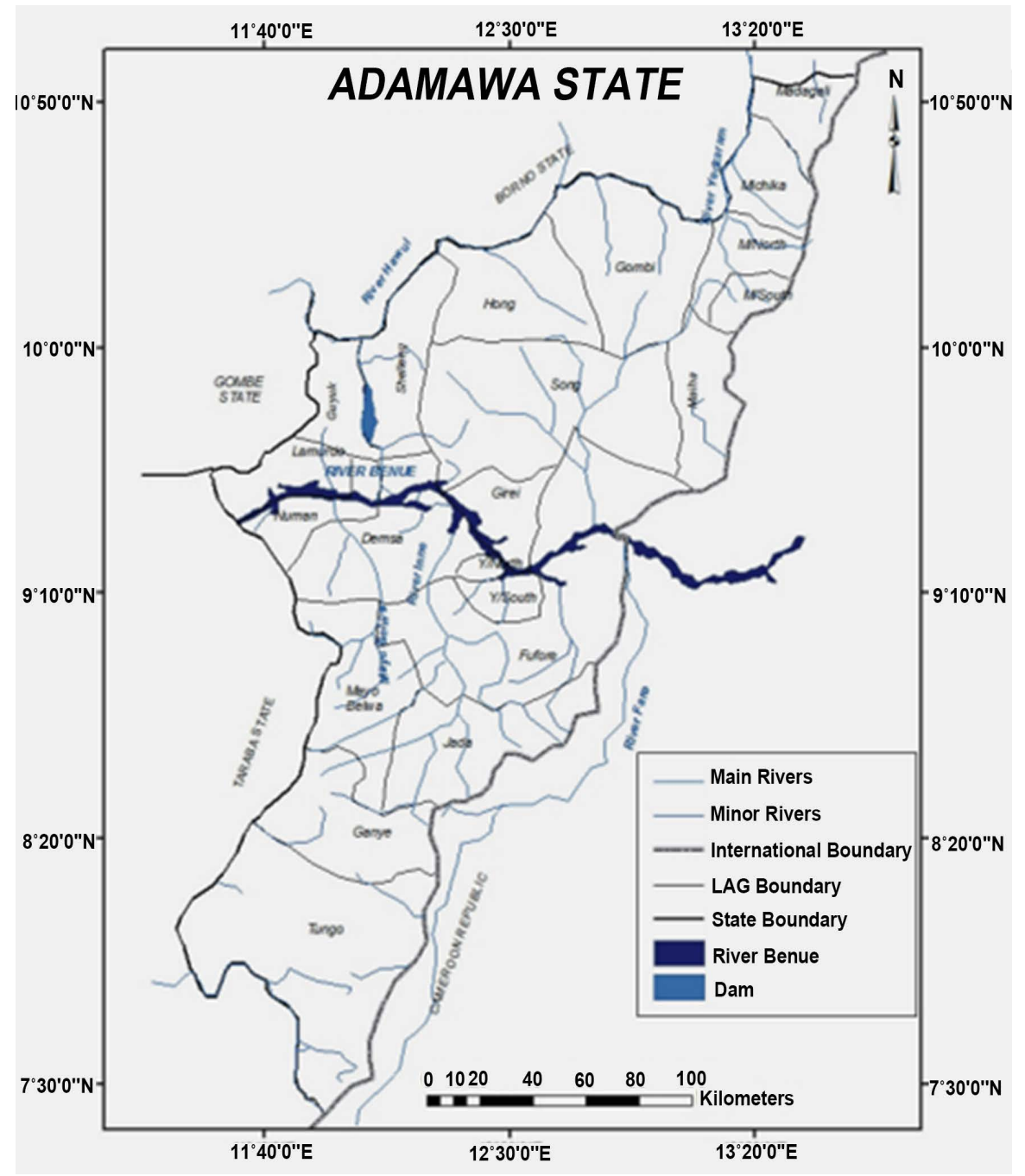

Figure 1. Jimeta map showing RIVER Benue.

areas namely, solid waste area, silt + solid waste area, silted area and no-silt; no-solid waste area (Figure 3). A $1 \mathrm{~m} \times 1 \mathrm{~m}$ quadrat was laid at an interval of 5 $\mathrm{m}$ within each plot as described by [11]. The plant specimens collected from the study areas were identified using literatures and also the help of experienced farmers in the study area. The plant species appearing in each of the site were identified counted and recorded. Plant species were identified using literatures [12] [13]. Estimation of plant cover, and population was extracted from the samples of plant collected at the site.

\subsection{Determination of Plant Cover and Density}

A visual estimate was made of the cover of individual species in the sample plots by using percentage classes given in the Domin and Braun-Blanquet scales [11]. The plant density was measured by counting the number of individual species within the quadrat in a unit area [14] (Greig-Smith, 1983). Relative density was calculated using the formula: 


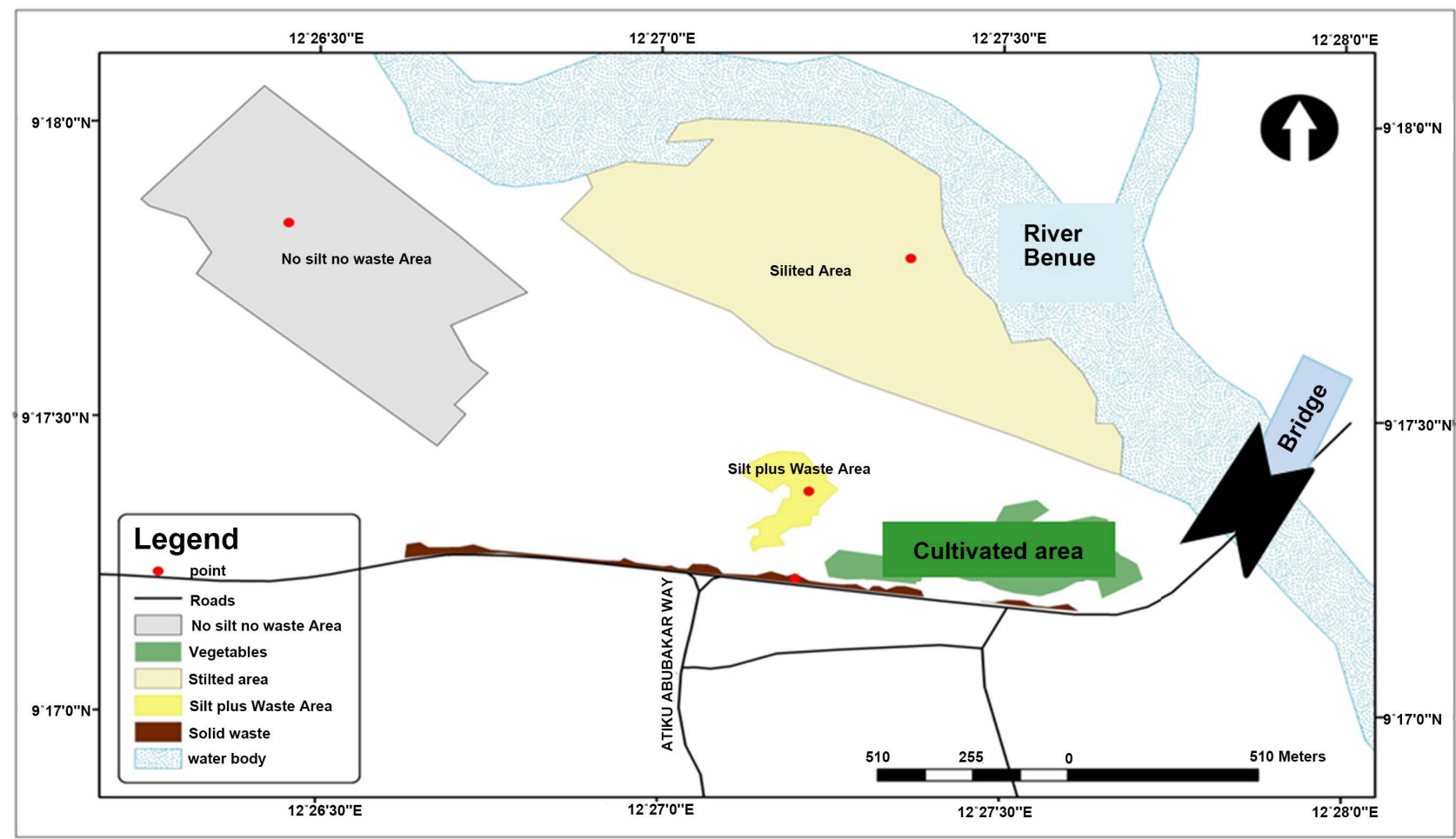

Figure 2. Map of the study area. Source: Field survey, (2015).

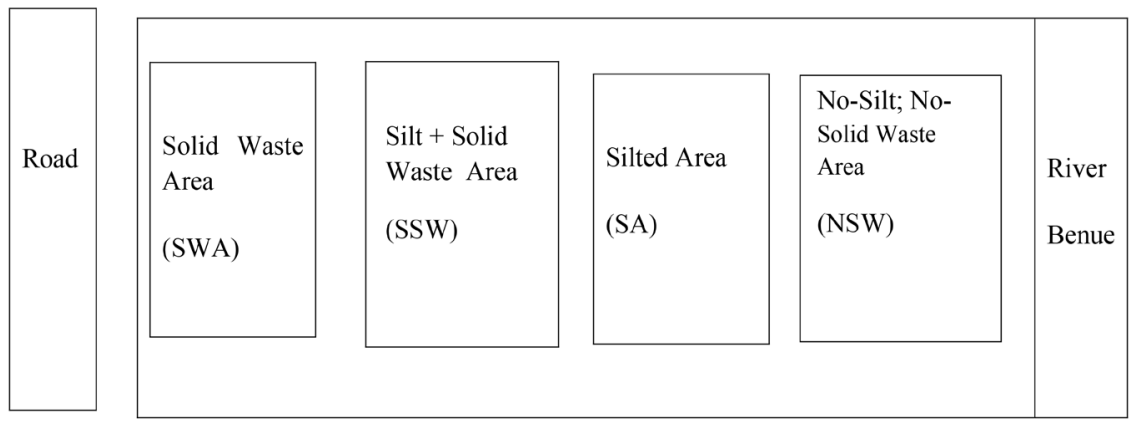

Figure 3. A diagrammatic layout of the sampling locations. Source: Field survey, (2015).

$$
\text { Relative density }=\frac{\text { number of individual of the species } \times 100}{\text { number of individual of all the species }}
$$

\subsection{Diversity of Herbaceous Plants Species Occurrence in the Study Area}

The computation of species diversity per plot was carried out using the Shannon-Wiener diversity index $\left(H^{\prime}\right)$ [16] from which each plant species was determined by multiplying the values of Pi by $100 \%$.

$$
\text { Shannon- Wiener Index }=\left(H^{\prime}\right)=-\sum(-P i I n P i)
$$

where $H^{\prime}=$ Diversity Index;

$P i=$ Proportion of a species in the whole sample population;

In = Natural Logarithm of the species; 
$\Sigma=$ Summation

Evenness index $(E)=H^{\prime} / H^{\prime} \max$

where: $H^{\prime} \max =\operatorname{In} S$ (where $S=$ total number of species).

One-way analysis of variance was done to compare the flora species found in the four plant communities.

The species richness of the vascular plants was calculated by using the method "Margalef's index of richness" (Dmg) [17].

$$
\text { Dmg }=(S-1) / \operatorname{InN}
$$

where,

$S=$ Total number of species.

$N=$ Total number of individuals.

\section{Results and Discussion}

\subsection{Checklists of Plant Species Identified in the Study Area}

Result of plants identified showed a total of 133 plants having 10, 9, 12 and 31 species at SWA, SSW, SA and NSW respectively. The total frequencies at each site were 18, 25, 31 and 59 at SWA, SSW, SA and NSW respectively. The result also shows that there were few individual plant species in the solid waste area. Axonopus compressus and Amarathus spinosus had the highest number 33.33\% and $22.22 \%$ respectively. The population of other herbaceous plant species at the SWA was low having $5.5 \%$ frequency each.

The result of plant species identified at silt + solid waste area indicated that there were 7 species belonging to four families; (Amarathaceae, Commelinaceae, Poaceae and Leguminosae). Commelina benghalensis has the highest frequency (28\%) followed by Axonopus compressus and Chrisopogon zizanioides with frequency of $20 \%$. The plant species with the lowest frequency was Mimosa invisa (4\%).

A total of 31 individual plants were identified in the silted area belonging to 12 species and 7 families (Poaceae, Cyperaceae, Euphorbiaceae, Cleomaceae, Leguminosae,Convolvulaceae and Asteraceae). Cynodon dactylon had 25.8\% frequency followed by Axonopus compressus with 19.3\% and Chrisopogon zizanioide with $16.1 \%$ frequency. Those with lowest frequency of 3.2\% were Cyperus iria, Cleome viscosa, Portulaca oleracea, Caesalpinia spp., Mimosa inuisa, Ipomoea involucrate, and Aspilia bussei.

Plants identified at no-silt; no-solid waste area revealed 31 plant belonging to Portulacaceae, Convolvulaceae, Nyctaginaceae, Leguminosae, Rubiaceae, Commelinaceae, Arecaceae, Mimosaceae, Cyperaceae, Boraginaceae, Cucurbitaceae, Verbenaceae, Euphorbiaceae, Asteraceae, Lamiaceae, Poaceae and Malvaceae families. Corchorus tridens, Corchorus olitorius, Axonopus compressus, Euphorbia hirta, Commelina benghalensis Luffa cylindrical, Acacia albida Chloris pilosa, Synedrella nodiflora and Hyphaene thebaica were some of the listed species of plants on this site. The most abundant was Corchorus tridens (13.55\%) 
followed by Corchorus olitorius (10.16\%) while the least abundant plant species in the area had $1.69 \%$ frequency.

Table 1 shows checklist of plant species in the four studied areas. The total population of plants in each area were 59, 31, 25 and 18 at the no-silt; no-waste, silted and silt + solid waste and solid waste area respectively. At the studied area the most common plant species in each site includes: Cynodon dactylon (8) for SA, Axonopus compressus (6) SWA, Commelina benghalensis (7) SSW, and Corchorus tridens (8) NSW. Table 1 also, clearly shows the most occurring plant species in the study area. This indicates the unevenness in individual plant species distribution. The NSW area had the highest number of plants 59 while the solid waste area had the lowest (18) number of plants as well as species abundance.

\subsection{Plant Species Diversity Index at the Studied Area}

The result obtained showed an approximate Shannon-Wiener diversity index $\left(H^{\prime}\right)$ values of $1.985,1.788,2.140$ and 3.125 indicating average uncertainties as the species were relatively distributed within the area at SWA, SSW, SA and NSW respectively (Tables 2-5). This signifies that an individual species picked at random might not be known being that, the plant species were fairly well represented in each of the study sites. In a species aggregation where each of the species is fairly well represented, it is difficult to predict the identity of a randomly sampled individual [18]. However, there is still need for urgent action to be taken to curtail anthropogenic activities and also to prevent deforestation leading to siltation, thereby causing a less stable habitat for flora species. According to [18], biologically realistic, $\mathrm{H}^{\prime}$ values range from 0 (no uncertainty as to what species each individual will be) to about 4.5 (high uncertainty as species are relatively evenly distributed, but in theory, the $H^{\prime}$ value can be much higher than 4.5 , although, most real world estimates of $\mathrm{H}^{\prime}$ range from 1.5 to 3.5. The findings of this study lay within these ranges for plant species diversity index.

The relative densities of the identified plant species revealed that Corchorus olitorius had 0.14, at NSW area. Cynodon dactylon had (0.25) at SA, followed by Axonopus compressus (0.019) and Chrisopogon zizanioides (0.16). At SSW, the relative density was (0.28) (Commenlina benghalensis) followed by $A$. compressuswith (0.2), Chrisopogon zizanioides and Amaranthus spinosus both had (0.12). SWA had a relative density of 0.35 ( $A$. compressus) followed by 0.18 ( $A$. spinosus). Species evenness (S) was approximately $0.69,0.56,0.62$ and 0.77 at SWA, SSW, SA and NSW respectively. This indicates that plant species are not evenly distributed within the studied area. Species richness shows 10 species at SWA, 7 at SSW, 12 at SA and 31 at NSW area. Also, from the one-way ANOVA result ( $\mathrm{p}$-value $=0.183377(\mathrm{p}<0.05)$ ), there is significant difference in plant species between the four studied sites (SWA, SSW, SA and NSW).

When considering total plant species richness, the results are in disagreement with the hypothesis that plant species occurrence along river Benue bank is not 
Table 1. Check list of plants in the study area.

\begin{tabular}{|c|c|c|c|c|}
\hline Plant species & Silted area & Solid waste area & Silt + solid waste area & No silt; no solid waste area \\
\hline Kyllinga erecta & 0 & 1 & 0 & 0 \\
\hline Aeschynomene indica & 0 & 1 & 0 & 0 \\
\hline Acalypha fimbriata & 0 & 1 & 0 & 1 \\
\hline Axonopus compressus & 6 & 6 & 5 & 1 \\
\hline Phyllanthus amarus & 0 & 0 & 0 & 1 \\
\hline Portulaca quadrifida & 0 & 0 & 0 & 1 \\
\hline Vernonia galamensis & 0 & 0 & 0 & 1 \\
\hline Hewitta sublobata & 0 & 0 & 0 & 1 \\
\hline Boerhavia diffusa & 0 & 0 & 0 & 2 \\
\hline Senna obtusifolia & 0 & 0 & 0 & 1 \\
\hline Mitracarpus villosus & 0 & 0 & 0 & 1 \\
\hline Commelina benghalensis & 0 & 0 & 7 & 1 \\
\hline Brachiaria deflexa & 0 & 0 & 0 & 2 \\
\hline Setaria barbata & 0 & 0 & 0 & 1 \\
\hline Mariscus longibracteatus & 0 & 0 & 0 & 1 \\
\hline Hyphaene thebaica & 0 & 0 & 0 & 4 \\
\hline Acacia albida & 0 & 0 & 0 & 2 \\
\hline Mariscus flabelliformis & 0 & 0 & 0 & 1 \\
\hline Heliotropium ovalifolium & 0 & 0 & 0 & 1 \\
\hline Platostoma africanum & 0 & 0 & 0 & 1 \\
\hline Luffa cylindrical & 0 & 0 & 0 & 1 \\
\hline Stachytarpheta cayennensis & 0 & 0 & 0 & 1 \\
\hline Euphorbia hirta & 0 & 0 & 0 & 5 \\
\hline Laggera aurita & 0 & 0 & 0 & 1 \\
\hline Leonotis nepetifolia & 0 & 0 & 0 & 1 \\
\hline Synedrella nodiflora & 0 & 0 & 0 & 1 \\
\hline Chloris pilosa & 0 & 0 & 0 & 1 \\
\hline Platostoma africanum & 0 & 0 & 0 & 1 \\
\hline Elytrophorus spicatus & 0 & 0 & 0 & 1 \\
\hline Calopogonium mucunoides & 0 & 0 & 0 & 2 \\
\hline Corchorus olitorius & 0 & 0 & 0 & 4 \\
\hline Corchorus tridens & 0 & 0 & 0 & 8 \\
\hline Paspalum vaginatum & 0 & 0 & 2 & 0 \\
\hline Ludiwigia hyssopifolia & 0 & 0 & 2 & 0 \\
\hline Mimosa invisa & 1 & 0 & 1 & 0 \\
\hline Cynodon dactylon & 8 & 1 & 0 & 0 \\
\hline Cyperus iria & 1 & 0 & 0 & 0 \\
\hline Portulaca oleracea & 1 & 1 & 0 & 0 \\
\hline Euphorbia heterophylla & 1 & 1 & 0 & 0 \\
\hline Cleome viscosa & 1 & 0 & 0 & 0 \\
\hline Caesalpinia spp & 1 & 0 & 0 & 0 \\
\hline Ipomoea involucrate & 1 & 1 & 0 & 0 \\
\hline Dactyloctenium aegyptium & 3 & 1 & 0 & 0 \\
\hline Aspilia bussei & 1 & 0 & 0 & 0 \\
\hline Chrysopogon zizanioides & 5 & 0 & 5 & 0 \\
\hline Amarathus spinosus & 0 & 4 & 3 & 4 \\
\hline Total & 31 & 18 & 25 & 59 \\
\hline
\end{tabular}

Source: Field survey, (2015). 
Table 2. Plants species diversity and evenness at solid waste area.

\begin{tabular}{|c|c|c|c|c|c|c|c|c|}
\hline Plant species & Frequency & $\mathrm{Pi}$ & Inpi & $p i($ Inpi) & Evenness & Richness (S) & Density & Relative Density \\
\hline Amarathus spinosus & 4 & 0.222222 & -1.50408 & 0.334239 & 0.686781 & 10 & 0.0075 & 0.176 \\
\hline Kyllinga erecta & 1 & 0.055556 & -2.89037 & 0.160576 & & & 0.0025 & 0.059 \\
\hline Aeschynomene indica & 1 & 0.055556 & -2.89037 & 0.160576 & & & 0.0025 & 0.059 \\
\hline Acalypha fimbriata & 1 & 0.055556 & -2.89037 & 0.160576 & & & 0.0025 & 0.059 \\
\hline Axonopus compressus & 6 & 0.333333 & -1.09861 & 0.366204 & & & 0.015 & 0.353 \\
\hline Cynodon dactylon & 1 & 0.055556 & -2.89037 & 0.160576 & & & 0.0025 & 0.059 \\
\hline Portulaca oleracea & 1 & 0.0555566 & -2.89037 & 0.160576 & & & 0.0025 & 0.059 \\
\hline Euphorbia heterophylla & 1 & 0.055556 & -2.89037 & 0.160576 & & & 0.0025 & 0.059 \\
\hline Ipomoea involucrate & 1 & 0.055556 & -2.89037 & 0.160576 & & & 0.0025 & 0.059 \\
\hline Dactyloctenium aegyptium & 1 & 0.055556 & -2.89037 & 0.160576 & & & 0.0025 & 0.059 \\
\hline Total & 18 & & & 1.985053 & & & 0.0425 & \\
\hline
\end{tabular}

Table 3. Plants species diversity and evenness at silt + solid waste area.

\begin{tabular}{|c|c|c|c|c|c|c|c|c|}
\hline Plant species & Frequency & pi & Inpi & $p i($ Inpi) & Evenness & Richness(s) & Density & Relative Density \\
\hline Amaranthus spinosus & 3 & 0.12 & -2.12026 & 0.254432 & 0.555321 & 7 & 0.0075 & 0.12 \\
\hline Commelina benghalensis & 7 & 0.28 & -1.27297 & 0.35643 & & & 0.0175 & 0.28 \\
\hline Paspalum vaginatum & 2 & 0.08 & -2.52573 & 0.202058 & & & 0.005 & 0.08 \\
\hline Ludiwigia hyssopifolia & 2 & 0.08 & -2.52573 & 0.202058 & & & 0.005 & 0.08 \\
\hline Mimosa invisa & 1 & 0.04 & -3.21888 & 0.128755 & & & 0.0025 & 0.04 \\
\hline Axonopus compressus & 5 & 0.2 & -1.60944 & 0.321888 & & & 0.0125 & 0.2 \\
\hline Chrisopogon zizanioides & 5 & 0.2 & -1.60944 & 0.321888 & & & 0.0125 & 0.2 \\
\hline Total & 25 & & & 1.787509 & & & 0.0625 & \\
\hline
\end{tabular}

Table 4. Plants species diversity and evenness at silted area.

\begin{tabular}{|c|c|c|c|c|c|c|c|c|}
\hline Plant species & Frequency & pi & Inpi & $p i(\operatorname{Inp} i)$ & Evenness & Richness(s) & Density & Relative Density \\
\hline Cynodon dactylon & 8 & 0.258065 & -1.35455 & 0.34956 & 0.623165 & 12 & 0.02 & 0.258064516 \\
\hline Cyperus iria & 1 & 0.032258 & -3.43399 & 0.110774 & & & 0.0025 & 0.032258065 \\
\hline Axonopus compressus & 6 & 0.193548 & -1.64223 & 0.317851 & & & 0.015 & 0.193548387 \\
\hline Portulaca oleracea & 1 & 0.032258 & -3.43399 & 0.110774 & & & 0.0025 & 0.032258065 \\
\hline Euphorbia heterophylla & 2 & 0.064516 & -2.74084 & 0.176828 & & & 0.005 & 0.064516129 \\
\hline Cleome viscosa & 1 & 0.032258 & -3.43399 & 0.110774 & & & 0.0025 & 0.032258065 \\
\hline Caesalpinia spp. & 1 & 0.032258 & -3.43399 & 0.110774 & & & 0.0025 & 0.032258065 \\
\hline Mimosa inuisa & 1 & 0.032258 & -3.43399 & 0.110774 & & & 0.0025 & 0.032258065 \\
\hline Ipomoea involucrate & 1 & 0.032258 & -3.43399 & 0.110774 & & & 0.0025 & 0.032258065 \\
\hline Dactyloctenium aegyptium & 3 & 0.096774 & -2.33537 & 0.226004 & & & 0.0075 & 0.096774194 \\
\hline Aspilia bussei & 1 & 0.032258 & -3.43399 & 0.110774 & & & 0.0025 & 0.032258065 \\
\hline Chrysopogon zizanioides & 5 & 0.16129 & -1.82455 & 0.294282 & & & 0.0125 & 0.161290323 \\
\hline Total & 31 & & & 2.139942 & & & 0.0775 & \\
\hline
\end{tabular}


Table 5. Plants species diversity and evenness at no-silt; no-solid waste area.

\begin{tabular}{|c|c|c|c|c|c|c|c|c|}
\hline Plant species & Frequency & pi & Inpi & $p i($ Inpi) & Evenness & Richness(s) & Density & Relative Density \\
\hline Phyllanthus amarus & 1 & 0.016949 & -4.07754 & 0.069111 & 0.766278 & 31 & 0.0025 & 0.024390244 \\
\hline Portulaca quadrifida & 1 & 0.016949 & -4.07754 & 0.069111 & & & 0.0025 & 0.024390244 \\
\hline Vernonia galamensis & 1 & 0.016949 & -4.07754 & 0.069111 & & & 0.0025 & 0.024390244 \\
\hline Hewitta sublobata & 1 & 0.016949 & -4.07754 & 0.069111 & & & 0.0025 & 0.024390244 \\
\hline Boerhavia diffusa & 2 & 0.033898 & -3.38439 & 0.114725 & & & 0.005 & 0.048780488 \\
\hline Senna obtusifolia & 1 & 0.016949 & -4.07754 & 0.069111 & & & 0.0025 & 0.024390244 \\
\hline Mitracarpus villosus & 1 & 0.016949 & -4.07754 & 0.069111 & & & 0.0025 & 0.024390244 \\
\hline Commelina benghalensis & 1 & 0.016949 & -4.07754 & 0.069111 & & & 0.0025 & 0.024390244 \\
\hline Brachiaria deflexa & 1 & 0.016949 & -4.07754 & 0.069111 & & & 0.0025 & 0.024390244 \\
\hline Setaria barbata & 1 & 0.016949 & -4.07754 & 0.069111 & & & 0.0025 & 0.024390244 \\
\hline Mariscus longibracteatus & 1 & 0.016949 & -4.07754 & 0.069111 & & & 0.0025 & 0.024390244 \\
\hline Hyphaene thebaica & 4 & 0.067797 & -2.69124 & 0.182457 & & & 0.001 & 0.009756098 \\
\hline Acacia albida & 2 & 0.033898 & -3.38439 & 0.114725 & & & 0.005 & 0.048780488 \\
\hline Mariscus flabelliformis & 1 & 0.016949 & -4.07754 & 0.069111 & & & 0.0025 & 0.024390244 \\
\hline Heliotropium ovalifolium & 1 & 0.016949 & -4.07754 & 0.069111 & & & 0.0025 & 0.024390244 \\
\hline Platostoma africanum & 1 & 0.016949 & -4.07754 & 0.069111 & & & 0.0025 & 0.024390244 \\
\hline Luffa cylindrical & 1 & 0.016949 & -4.07754 & 0.069111 & & & 0.0025 & 0.024390244 \\
\hline Acalypha fimbriata & 1 & 0.016949 & -4.07754 & 0.069111 & & & 0.0025 & 0.024390244 \\
\hline Stachytarpheta cayennensis & 1 & 0.016949 & -4.07754 & 0.069111 & & & 0.0025 & 0.024390244 \\
\hline Euphorbia hirta & 5 & 0.084746 & -2.4681 & 0.209161 & & & 0.0125 & 0.12195122 \\
\hline Laggera aurita & 1 & 0.016949 & -4.07754 & 0.069111 & & & 0.0025 & 0.024390244 \\
\hline Leonotis nepetifolia & 1 & 0.016949 & -4.07754 & 0.069111 & & & 0.0025 & 0.024390244 \\
\hline Amarathus spinosus & 4 & 0.067797 & -2.69124 & 0.182457 & & & 0.001 & 0.009756098 \\
\hline Synedrella nodiflora & 1 & 0.016949 & -4.07754 & 0.069111 & & & 0.0025 & 0.024390244 \\
\hline Chloris pilosa & 1 & 0.016949 & -4.07754 & 0.069111 & & & 0.0025 & 0.024390244 \\
\hline Platostoma africanum & 1 & 0.016949 & -4.07754 & 0.069111 & & & 0.0025 & 0.024390244 \\
\hline Elytrophorus spicatus & 1 & 0.016949 & -4.07754 & 0.069111 & & & 0.0025 & 0.024390244 \\
\hline Calopogonium mucunoides & 2 & 0.033898 & -3.38439 & 0.114725 & & & 0.005 & 0.048780488 \\
\hline Axonopus compressus & 4 & 0.067797 & -2.69124 & 0.182457 & & & 0.001 & 0.009756098 \\
\hline Corchorus olitorius & 6 & 0.101695 & -2.28578 & 0.232452 & & & 0.015 & 0.146341463 \\
\hline Corchorus tridens & 8 & 0.135593 & -1.9981 & 0.270928 & & & 0.002 & 0.019512195 \\
\hline Total & 59 & & & 3.124526 & & & 0.1025 & \\
\hline
\end{tabular}

Source: Field survey, (2015).

influenced by siltation and solid waste effluents. However plant species were high at the NSW area which might be as a result of the higher species diversity which increased productivity. This concurs with the findings of [19], in their research on Plant diversity and productivity experiment in European grasslands. They reported that in experimental grassland, plant communities increased 
productivity as a result of higher species diversity. In the present study amongst all the study sites, the increase in plant species diversity was observed more in NSW area (Table 5), which had not been polluted by either silt or waste effluents. This corroborates the result of [20] who stated that amongst all the study stations (1 - 10) sited on the banks of the confluence of the Mula and Mutha Rivers, in Pune city at the south west of India stations 5 and 9 (Vitthalwadi Holkar Bridge) were represented as most diverse. It has highest species richness due to relatively less human intervention, whereas station 6 and 8 (Garware and Dapodi) were having the least species Shannon diversity index as a result of reasonably high population pressure, apparently patchy vegetation due to biotic inference involving farming practices, habitat destruction and domestic livestock.

The Shannon-Wiener diversity index revealed that there is significant difference in the four studied areas which is in disagreement with [20]. Their Shannon-Wiener diversity index had no significant difference among the various stations. This suggests that the species were somehow distributed rather evenly. However, there were significant differences in species relative abundance and density in this study. The results also indicated that species were not distributed uniformly, rather appearing in patches. This distribution may perhaps be as a result of the human interference in the natural vegetation over long period.

The Figure 4 line Chart shows the abundance of herbaceous plant species at various sampling locations. It reveals the relative range of distribution of various species in the study area. Most of the Species were restricted to each study site where they were found and rare in other sites. The species having wide range of distribution and abundant in occurrence include Cynodon dactylon (8) for SA, Axonopus compressus (6) SWA, Commelina benghalensis (7) SSW, and Corchorus tridens (8) NSW. The species occurrence level at the silted area is quite remarkable particularly with the level of silt deposited in such area which is at the river bed. A similar report by [20], stated that Alternanthera sessilis, Ludwigia octovalvis, Eichhornia crassipes, Parthenium hysterophorus etc. were having wide range of distribution and abundant in occurrence in river bed particularly in urban areas.

\section{Conclusion}

There are variations in the individual number of plant species in the study area and the distribution is not even in the studied sites. Effluents from the solid waste and the silt depth level in the area could be among the factors threatening and causing variations in plant species diversity in the area as seen in the report. The land use system (farming) which involved the use of some chemicals, in the study sites, could also be the reason for inadequate natural regeneration in the area as this chemical content may be harmful to some flora species.

\section{Recommendations}

If the current trend of deforestation at the expense of the natural environment continues, the effects would be greater than the intending benefits of the 


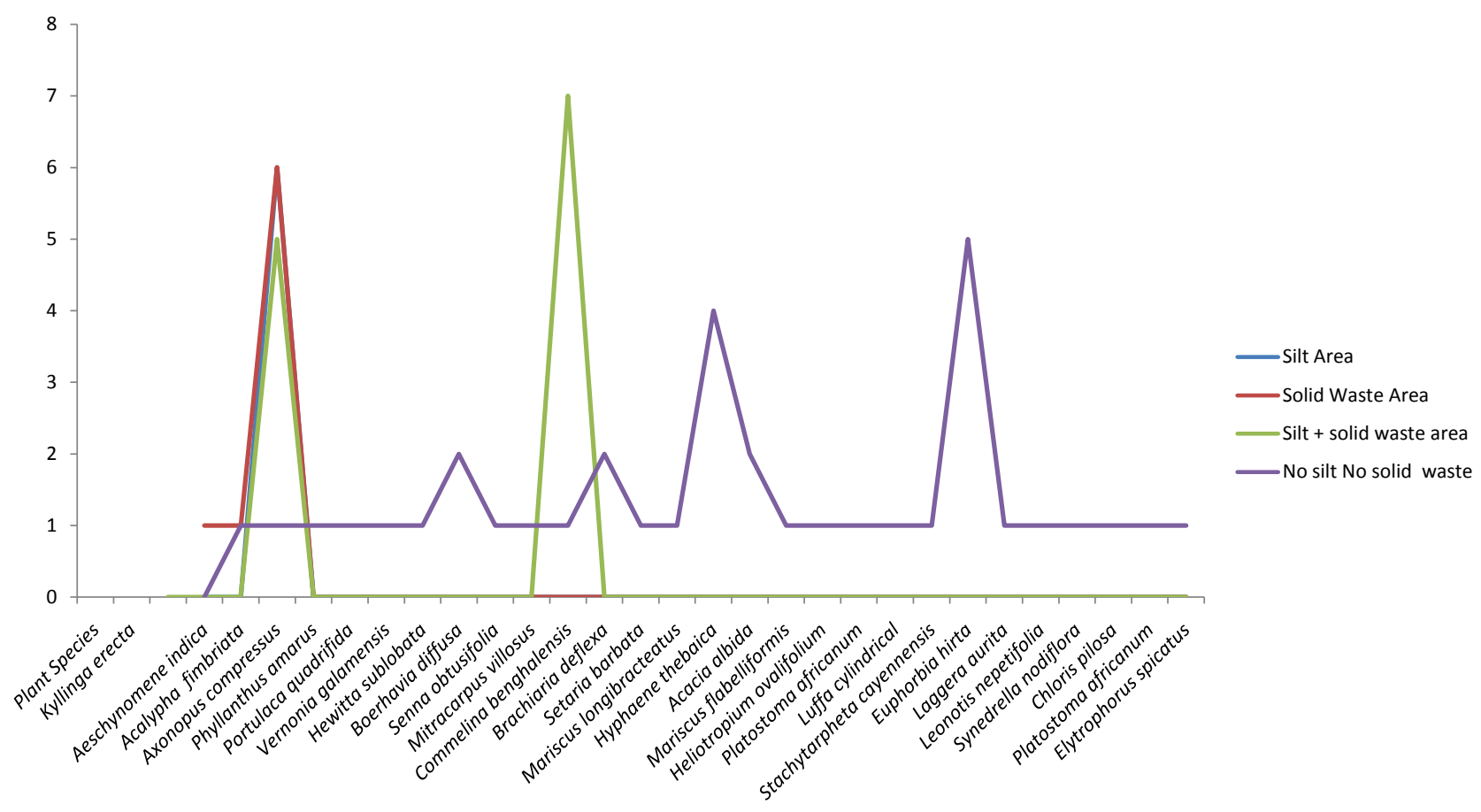

Figure 4. Abundance of herbaceous plant species at the study sites. Source: Field survey, (2015).

product. However, various measures could be considered in an attempt to reduce the negative effects of anthropogenic activities on the environment and to prevent future impacts on the ecosystem. Artificial regeneration should be encouraged in areas with trait of flooding and tree planting should be considered as part of all developmental projects. Appropriate laws and legislations on tree harvesting, bush burning and animal grazing should be established. To control waste effluents we strongly recommend that government should support industrial recycling activities such as those for used batteries, used paint, used pesticides, used oil and electronic wastes such as used computers and cell phones. Environmentally friendly products should be purchased whenever possible.

\section{References}

[1] Keddy, P.A. (2007) Plants and Vegetation. Cambridge University Press, Cambridge, 680. https://doi.org/10.1017/CBO9780511812989

[2] Emma, O., Lilian, C., Ibeawuchi, Izuchukwu, I. and Obiefuna, J.C. (2010) Biodiversity Conservation for Sustainable Agriculture. New York Science Journal, 3 p.

[3] Lekwa, G. and Whiteside, E.P. (1996) Coastal Plain Sand of South-Eastern Nigeria. Soil Science Society of American Journals, 50,154-160. https://doi.org/10.2136/sssaj1986.03615995005000010029x

[4] Happold, D.C.D. (1987) The Mammals of Nigeria. Oxford University Press, Oxford.

[5] Stuart, S.N., Adams, R.J. and Martin, J. (1990) Biodiversity in Sub-Saharan Africa and Its Islands: Conservation, Management, and Sustainable Use. Biodiversity Conservation Strategy Programme, International Union for Conservation of Nature and Natural Resources. Species Survival Commission, IUCN, 242 p.

[6] Adefioye, S.A. (2013) Analysis of Land Use/Land Cover Pattern along the River 
Benue Channel in Adamawa State, Nigeria. Department of Geography, Obafemi Awolowo University, Ile Ife. Nigeria Academic Journal of Interdisciplinary Studies, 2, 128-138.

[7] Canback Global Income Distribution Database (C-GIDD) (2008) Canback Dangel. https://en.wikipedia.org/wiki/Bauchi_State Adamawa. https://en.wikipedia.org/wiki/Adamawa_Region

[8] Adebayo, A.A. and Tukur, A.L. (1999) Climate: Sunshine, Temperature, Evaporation and Relative Humidity. Climate II: Rainfall. In: Adebayo, A.A. and Tukur, A.L., Eds., Adamawa State in Maps, Department of Geography and Paraclete Publishers, 20-26.

[9] Clegg, C.J., Mackean, D.G., Openshow, P.H. and Reynoids, R.C. (1996) Advanced Biology Study Guide, Principles and Applications. John Marray (Publishers), London, 21-29.

[10] Barbour, M.G., Burk, J.H. and Pitt, W.D. (1987) Terrestrial Plant Ecology. 2nd Edition, Benjamin Cummings Publishers, New York, 37.

[11] James, B. (1996) Furzebrook Research Station, NERC Institute of Terrestrial Ecology, Wareham, Dorset BH20 5AS, United Kingdom. In: Sutherland, W.J., Ed., Ecological Census Techniques-A Handbook, 111-115.

[12] Michel, A. (2004) Trees, Shrubs and Lianas of West African Dry Zones. 6700 AJ Wageningen, The Netherlands. CIRAD, Margraf Publishers GMBH, MNHN, 33-513.

[13] Schmelzer, G.H. and Gurib-Fakim, A., Eds. (2008) Plant Resource of Tropical Africa 11 (1) Medicinal Plants 1. PROTA Foundation, Wageningen, Netherlands/ Backhuys Publishers, Leiden, Netherlands/CTA, Wageningen, Netherlands, 791.

[14] Greig-Smith, P. (1983) Quantitative Plant Ecology. 3rd Edition, Blackwell Science Publications, Oxford, 359 p.

[15] Curtis, J.T. and McIntosh, R.P. (1950) The Interrelations of Certain Analytic and Synthetic Phyto-Sociological Characters. Ecology, 31, 434-455. https://doi.org/10.2307/1931497

[16] Shannon, C.E. and Weaver, W. (1949) The Mathematical Theory of Communication. University of Illinois Press, Urbana.

[17] Magurran, A.E. (1988) Ecological Diversity and Its Measurement. Princeton University Press, Princeton. https://doi.org/10.1007/978-94-015-7358-0

[18] Wagggoner, C.M., Keller, K. and McArthur, J. (2003) Exploring Biodiversity. In: O’Donnell, M.A., Ed., Tested Studies for Laboratory Teaching, Volume 24, Proceedings of the $24^{\text {th }}$ Workshop/Conference of the Association for Biology Laboratory Education (ABLE), 1-6.

[19] Hector, A., Schmid, B., Beirrkuhnlein, C., Caldeiria, M.C. and Diemer, M. (1999) Plant Diversity and Productivity Experiment in European Grasslands. Journal Science, 286, 1123-1126. https://doi.org/10.1126/science.286.5442.1123

[20] Ghavzan, N.J., Gunale, V.R., Mahajan, D.M. and Shirke, D.R. (2006) Effects of Environmental Factors on Ecology and Distribution of Aquatic Macrophytes. Asian Journal of Plant Sciences, 5, 871-880. https://doi.org/10.3923/ajps.2006.871.880 